Departamento de Anatomia Descritiva dos Animais Domesticos Prof. Dr. M. Barros Erhart

\title{
DEMARCAÇÃO DAS REGIÕES DA CABEÇA NO CAVALO
}

POR

\section{Plinio Pinto e Silva e Armando Chieffi \\ Assistentes \\ Com 4 estampas}

O escôpo principal do presente trabalho é o de tornar possivel delimitar qualquer região da cabeça no cavalo tomada isoladamente, sem o auxilio prévio de uma figura e dêsse modo, conseguir localizar e demarcar a parte que se pretende estudar. Este estudo se justifica, pois que todos os tratados de Ezoognosia por nós compulsados (*), limitam-se unicamente a denominar as regiões da cabeça do cavalo e de outros mamiferos domesticos e, quanto à demarcação das mesmas, apenas apresentam figuras esquemáticas, ou enumeram a situação em relação às regiões limítrofes, sem citar pontos de reparo, quer superficiais, quer profundos.

Quanto aos tratados de Anatomia Topográfica, com exceção de Ellenberger e Baum, que limita as regiões da cabeça, não usando, porém, «in totum» o esquema adotado em Exterior, e de RUBAy, MONGIARDINO, que determinam os limites para uma ou outra região, os demais se abstêm em precisar os limites, usando o criterio dos AA. de Exterior.

Em Anatomia Descritiva, os limites dados pelos tratados clássicos para a divisão do crâneo em nórmas ou regiões, se relacionam aos planos profundos e, os pontos de reparo, são geralmente as suturas ósseas. Sob o ponto de vista Ezoognosico, porém, não nos podendo servir dêstes limites profundos, faremos o possivel para transportá-los para o exterior, traçando linhas convencionais e tomando como pontos de referencia, saliências ósseas, depressões, ou mesmo saliências musculares.

Para localizar e delimitar as diversas regiões da cabeça do cavalo, serviram de orientação as figuras esquemáticas dos tratados de Exterior e Anatomia Topográfica. Partindo dêstes esquemas, foram as linhas decalcadas sôbre a cabeça de um animal fixado por injeção arterial de formól a $10 \%$, ainda recoberta pela péle e depois transportadas para o vivo, sendo procuradas as particularidades anatômicas descritivas e linhas imaginárias convencionais, que permitiram a reunião dos pontos certos e conhecidos, de módo a tornar possivel delimitar as diversas regiões.

(*) Deixamos de citar os nomes dos AA. porque sâo os que constam da lista bibliográfica. 
Naturalmente, não devem ser levadas em conta as pequenas variações decorrentes das diferenças relativas individuais e, principalmente, das raciais.

\section{ESTUDO DAS REGIÕES}

A cabeça póde ser considerada estendendo-se até o limite posterior das regiões da nuca, parótidas e garganta, porções estas que em muitos tratados são consideradas como fazendo parte do pescoço, e, em outros, como partes intermediárias entre este último e a cabeça. Nós as estudaremos, como Goubaux e Barrier, le Hello, Bourdelle e Bressou, Marce e Lahaye e Duerst, incluindo-as na extremidade superior da cabeça.

Todos os AA. são concórdes em dar à cabeça do cavalo a fórma de uma pirâmide quadrangular, com ápice truncado, apresentando quanto à situação e orientação: uma face anterior, duas faces laterais, uma face posterior, uma extremidade inferior ou ápice e uma extremidade superior ou báse. Tal descrição facilita nosso objetivo, pois permite demarcar, nas faces, as diversas regiões em que é dividida a cabeça.

\section{A - FACE ANTERIOR}

$\mathrm{Na}$ face anterior da cabeça, estão localizadas: a fronte, o chanfro e a extremidade do nariz.

Fronte: - E' a região ímpar que se colóca na parte anterosuperior da cabeça. (Est. 1 e $2 \mathrm{~A}$ ).

Limites: - A fronte é limitada posteriormente, com a região da nuca; inferiormente, com o chanfro; lateralmente, com as orelhas, têmporas, olhais, regiões orbitárias (olhos) e pequena parte das parótidas.

Linhas de demarcação: - A demarcação aboral desta região é dada por uma linha transversal, traçada no ponto mais alto da cabeça, em correspondencia à protuberância occipital externa. Esta linha limita a fronte com a nuca. Oralmente, a fronte separa-se do chanfro pela transversal que une os dois angulos mediais dos olhos. A demarcação lateral é dada por uma linha que, partindo da porção mais lateral da demarcação posterior, onde se nota a reflexão da péle sôbre a orelha, se continúa margeando medialmente a báse do pavilhão; contórna, em seguida, a arcada zigomática em sua margem dorsal e atinge o sulco formado pela porção oral do músculo crotafito. Segue êste sulco, que separa a fronte dos olhais, até atingir a crista temporal do osso frontal; muda, agora, de direção, seguindo pela crista (fàcilmente palpável) e vai ter à parte média da inserção da pálpebra superior. Contórna, em direção oral, esta inserção, até o angulo interno do olho, onde atinge a linha de demarcação oral. 
Descrição: - A fronte, nos equinos, é uma região que pode ser dividida em duas partes: uma aboral ou parietal e outra oral ou frontal propriamente dita, visto ter por báse óssea os parietais e os frontais.

A parte mais aboral ou parietal da fronte é recoberta, na linha mediana, pelas crinas do topéte; lateralmente, são notadas duas saliências representadas pelos músculos crotafitos, e, delimitando as mesmas, no plano sagital, existem duas cristas - cristas temporais - conformadas em $\mathrm{V}$, com vértice aboral que podem ser percebidas pela palpação.

A fronte é recoberta externamente por uma péle espessa, aderente à fascia aponevrótica. Nesta região, em todos os animais, ha um certo número de pêlos que toma uma orientação invérsa à natural (espiga). A disposição dos pêlos, na espiga, é tão caracteristica, a ponto de permitir a identificação. Nos animais de pelagem escura, a espiga é constituida por pêlos brancos, justificando a denominação de «animal com estrela ou luzeiro».

Chanfro: - E' uma região impar, situada na face anterior da cabeça, que se estende dêsde a fronte até as ventas. (Est. 1e $2 \mathrm{~B}$ ).

Limites: - Para a maior parte dos AA., esta região é limitada superiormente pela fronte; inferiormente pela extremidade do nariz; de cada lado pelos olhos, bochechas e narinas. Como a região do chanfro, invade a porção da face que tem por báse os óssos zigomáticos e lacrimais, que, por sua vez, concorrem para a delimitação das arcadas orbitárias, somos levados a colocar as regiões orbitárias (olhos) em seu limite posterior.

Linhas de demarcação: - Usando o critério acima, consideraremos, na demarcação aboral, uma porção média, correspondendo à fronte, e outra lateral juxtaposta à região orbitária.

A linha transversal que une os dois angulos mediais dos olhos separa a sua porção média, da fronte; a partir do angulo medial do olho, demarca-se a porção lateral, seguindo a inserção da pálpebra inferior até a saliência dada pela crista facial, linha que separa o chanfro da região orbitária. Oralmente uma transversal que une as comissuras nasais superiores, cruza o plano sagital ao nivel da extremidade oral dos óssos nasais, ou melhor, da cartilagem lateral e separa esta região da extremidade do nariz. Lateralmente, a linha de demarcação será dada pela saliência da crista facial, continuando-se oralmente por uma réta que alcança o contorno da narina, aproximadamente na metade de sua porção aboral; segue este contôrno, a um centímetro, mais ou menos, do bórdo livre, até a comissura nasal superior, onde alcança 
o limite oral. Fica portanto, incluido nesta região o divertículo cutâneo nasal, formação anatômica particular dos equinos.

Descrição: - Três porções podem ser consideradas nesta região: uma mediana e duas laterais. A primeira tem como báse óssea principal, os ossos nasais, é bem mais saliênte do que as porções laterais e, de conformidade com sua orientação, determina os diversos perfís do animal. Assim, quando retilínea, contribúe para a formação da cabeça quadrada, de perfil réto; quando convexilinea, o perfil será acarneirado e, quando côncava, determinará a denominada cabeça de rinoceronte. As duas outras porções, isto é, as partes laterais do chanfro, bombeadas nos animais jovens por possuirem ainda os dentes pré-molares definitivos contidos nos alvéolos, tornam-se planas após a erupção dos dentes permanentes e mesmo excavadas com o aumentar da idade do animal.

A báse óssea das partes laterais é formada, principalmente pelo maxilar superior e, mais aboralmente, pelo zigomático e lacrimal.

O agrupamento de pêlos brancos, ocupando zonas mais ou menos estensas do chanfro, permite dar ao animal as seguintes denominações: animal com cordão - si, da estrela ou luzeiro, a mancha se continuar pelo chanfro por um pequeno risco que se dirige para a extremidade do nariz. O cordão ou filete pode apresentar-se completo ou incompleto;

animal frente aberta - quando o cordão se mostra largo e desce atravessando o chanfro, até a extremidade do nariz;

animal mala cara - quando toda ou grande parte da face anterior da cabeça é recoberta por pelagem branca;

animal com embornal - quando, do chanfro para baixo, a pelagem apresenta-se branca;

animal com cabeçada de mouro - si, na mesma região vista anteriormente, a pelagem se apresentar preta. Si toda a cabeça fôr dessa côr, terá a denominação de cabeça de mouro.

Extremidade do nariz: - E' a região da face anterior da cabeça que se acha em situação mais oral (Est. 1 e 2C).

Limites: - Situada entre as narinas, que the ficam lateralmente, a extremidade do nariz limita-se aboralmente com o chanfro e, oralmente, com o lábio superior.

Linhas de demarcação: - Aboralmente, separa-se do chanfro pela linha transversal dada pelo limite oral desta região, isto é, a que reúne as comissuras nasais superiores. Oralmente separa-se dos lábios pela transversal que corresponde internamente ao sulco gengivo-labial superior e que, transportado para a superfície, demarca a 
extremidade do nariz em toda sua extensão. Os limites laterais são dados por uma linha, convexa medialmente, traçada no sentido aboraloral, ligando as linhas de demarcação extremas.

Descrição: - A extremidade do nariz, bastante móvel, acha-se recoberta por uma péle fina extremamente aderente aos planos profundos. Em alguns animais pode aparecer uma pequena mancha de coloração branca que se denomina "béta».

\section{B - FACES LATERAIS}

A face lateral da cabeça, que se estende da parótida à região labial, compreende as regiões auricular (orelha), da têmpora, olhais, região orbitária (olhos), bochecha e narina.

Região auricular (orelha): - E' uma região situada na parte superior da cabeça, de cada lado e anteriormente à nuca (Est. $1-2 \mathrm{e} 4 \mathrm{D}$ ).

Limites: - Limita-se medialmente com a fronte e se colóca superiormente à parótida que invade seu bórdo oral.

Linhas de demarcação: - A linha de demarcação desta região é de contôrno circular, corresponde ao ponto de reflexão da péle que recobre a cartilagem da concha, sôbre as regiões vizinhas.

Descrição: - A expressão - orelhas - em exterior, não significa todo o aparelho auditivo, mas simplesmente a concha que é uma expansão da péle conformada em corneto, tendo um arcabouço cartilaginoso que contórna o orifício do meato acústico externo. $\mathrm{O}$ pavilhão auricular é recoberto externamente por uma péle fina, bastante aderente, através da qual desenham-se alguns vasos superficiais com trajéto sinuoso. Internamente, apresenta-se ela mais delgada, rósea, entremeada de pêlos longos, finos e entrelaçados, que servem para amortecer os ruídos e impedir a penetração de corpos extranhos.

Sendo a péle muito aderente aos planos profundos, qualquer compressão que se faça ou um processo inflamatório que aí se desenvolva, são bastante dolorosos. Este apêndice, pela sua sensibilidade e fácil apreensão, pode ser usado como meio de contenção.

Conforme a orientação tomada pelo pavilhão auricular, recebem, os cavalos, denominações diversas que não serão aqui tratadas, porquanto, cabem mais num trabalho exclusivamente de ezoognosia.

Têmpora: - Região par, situada na face lateral da cabeça, corresponde à parte externa da articulação têmporo-mandíbular (Est. 1 e 2 E). 
Limites: - Inferiormente é limitada pela porção masseterina (chato da bochecha), superiormente pelos olhais e fronte, aboralmente, separa-se da orelha por pequena porção da parótida e, oralmente, relaciona-se com a região orbitária.

Linhas de demarcação: - Superiormente separa-se da fronte e dos olhais por uma linha de concavidade inferior, marcada na superfície pelo bórdo superior da arcada zigomática, linha esta que se estende até a região palpebral, ponto que corresponde mais ou menos à parte média da arcada. Inferiormente ou lateralmente, a demarcação desta região é dada pelo bórdo inferior da arcada, dêsde seu meio, até atingir aboralmente o cólo do côndilo da mandíbula. Esta linha separa a têmpora da bochecha. O limite anterior é dado pela linha de inserção da pálpebra superior, reunião dos limites superior e inferior, ou pela linha que cruza a face lateral da arcada zigomática, em seu meio. A demarcação aboral é dada por uma linha que, passando pela parte mais saliênte do rebórdo posterior do côndilo da mandíbula, reúne os limites superior e inferior.

Descrição: - O plano cutâneo desta região é bastante delgado e móvel, notando-se, principalmente nos animais de pelagem escura, o aparecimento dos primeiros pêlos brancos que caracterizam, para alguns AA., a idade avançada do animal. Tais pêlos, no entretanto, podem ser notados tambem em pôtros.

Não é raro, nesta região, aparecerem excoriações ou depilações, consequencia de um decúbito prolongado.

Olhais: - Região par, situada postero-superiormente à arcada orbitária, representada por uma depressão que corresponde à fóssa orbito-temporal (Est. $1 \mathrm{e} 2 \mathrm{~F}$ ).

Limites: - Os olhais colocam-se aboralmente aos olhos; medialmente e oralmente limitam-se com a fronte e lateralmente, com as têmporas.

Linhas de demarcação: - Aboralmente, separa-se da fronte por uma linha que corresponde à saliência do bórdo oral do músculo temporal, recoberto em parte pelo coxim adiposo que preenche a fóssa órbito-temporal, e que se estende da crista temporal do osso frontal, até o bórdo superior da arcada zigomática. A linha de demarcação medial e oral é dada pela porção da crista temporal do frontal, na parte que esta se estende pelo bórdo posterior do processo zigomático do mesmo osso, até a parte média do bórdo superior da arcada zigomática que separa os olhais medialmente da fronte, e, oralmente, da região orbitária. Lateralmente segue a saliência, muito nítida, formada pelo 
bórdo superior da arcada zigomática, que constitúe o limite de separação entre os olhais e a têmpora.

Descrição: - A péle que recóbre os olhais dobra-se entre os dedos com muita facilidade. Preenchendo toda a região acha-se um coxim adiposo que recóbre o processo coronóide da mandíbula e está em contacto íntimo com o mesmo. Os olhais não devem ser muito profundos, pois isto indicaria cansaço ou velhice do animal e contribuiria para a formação da cabeça descarnada.

Região orbitária: - Aplicamos esta denominação (região orbitária) para designar o que vulgarmente, em Ezoognosia, se denomina olhos. (Est. 1 e $2 \mathrm{G}$ ). Achamos a primeira mais exata, porquanto, além do órgão essencial da visão - globo ocular - são estudados, nesta região, seus anexos, como: pálpebras, músculos motôres do globo ocular, membrana nictitante, etc.. Como o fim deste trabalho é principalmente o de delimitar as regiões e descrever sucintamente as particularidades de superfície, não cogitaremos de detalhes referentes à anatomia do globo ocular e seus anexos, exceção feita das pálpebras.

Limites: - Região situada de cada lado da fronte, acima da bochecha, anteriormente à têmpora e olhais e posteriormente ao chanfro.

Linhas de demarcação: - A região orbitária é perfeitamente limitada por um círculo ósseo, correspondendo ao bórdo da arcada orbitária, círculo êste formado pelo osso frontal, seu processo zigomático, processo zigomático do temporal, ossos zigomático e lacrimal. Para se demarcar esta região, basta seguir o ponto de inserção das pálpebras, em toda sua extensão.

Descrição: - Afim de tornar mais claro o estudo da região orbitária, haveria necessidade de lembrar alguns conhecimentos da anatomia do globo ocular e de suas partes anexas, que, como dissémos anteriormente, não serão abordados, pois que iriam prolongar muito esta nota, caso fôsse por nós empreendido, e ultrapassaria os fins a que nos propusemos. A descrição das pálpebras é porém de algum interesse - porquanto pela fórma, defeitos, implantação, fendidura, etc., a região recebe denominações particulares.

As pálpebras são duas prégas cutâneas, bastante móveis, que, pela sua posição, são distíntas em superior e inferior.

Ambas possúem: $10^{\circ}$ ) uma face externa, convexa, recoberta pela péle e dividida em 2 partes desiguais pelo súlco órbito-palpebral; $2 .^{\circ}$ ) dois bórdos - um aderente, correspondendo ao contôrno da cavidade orbitária e outro livre, côncavo na pálpebra superior e quasi retilíneo na inferior. Os bórdos são fortemente pigmentados e divididos 
em duas partes: uma externa, onde se implantam os cílios: outra interna, onde são vistas pequenas aberturas representando a desembo. cadura dos canais das Gll. tarseae Meibomi; $3 .^{\circ}$ ) duas comissuras, união dos bórdos livres, distíntos em interna, nasal ou medial e externa ou lateral.

Bochecha: - E' uma região par, que compreende a maior parte da face lateral da cabeça, estendendo-se da parótida à comissura dos lábios e do chanfro à ganacha, (Est. 2 e $3 \mathrm{H}$ ). Encarada sob o ponto de vista ezoognosico, pode ser ela dividida em duas regiões distintas, bem delimitadas pela saliência do bórdo anterior do músculo masséter. A porção posterior, chato da bochecha ou porção massetérica, é delimitada aboralmente pelo ramo montante da mandíbula e corresponde totalmente ao músculo masséter. A porção anterior, bolsa ou bochecha própriamente dita, corresponde ao músculo bucinador e separa-se do chanfro pela crista facial, estendendo-se até a comissura labial.

Limites: - Superiormente limita-se com as regiões da têmpora, orbitária e do chanfro; inferiormente com a ganacha; aboralmente com a parótida e oralmente com a comissura dos lábios.

Linhas de demarcação: - Aboralmente, a linha de demarcação é dada por toda a extensão do ramo montante da mandíbula, dêsde o angulo até o côndilo, separando esta região da parótida. Oralmente, por uma linha de concavidade anterior, que partindo da margem postero-lateral da protuberância do mento, acompanha o músculo orbicular dos lábios, contórna a comissura labial, mais ou menos à distância de um centímetro e atinge o ponto que corresponde aproximadamente à metade da porção aboral do contôrno da narina. Superiormente, a bochecha separa-se da têmpora, região orbitária e chanfro, por uma linha que, partindo do bórdo posterior do ramo montante da mandíbula, ao nivel do cólo, continúa pela margem inferior da arcada zigomática, pela crista facial e por uma réta que se prolonga desta, até alcançar o contôrno da narina, aproximadamente na metade de sua porção aboral.

Ventralmente demarca-se esta região pela linha que parte do angulo da mandíbula e se dirige para diante, seguindo o bórdo inferior do músculo masséter; além dêste, se continúa pelo bórdo ventral do ramo da mandíbula até chegar à margem postero-lateral da protuberância do mento, unindo-se à linha limítrofe oral.

Descrição: - $\mathrm{Na}$ parte anterior desta região - bolsa ou bochecha pròpriamente dita - percebemos uma estreita coluna carnósa, 
o M. depressor do lábio inferior que muito bem se destaca sob a péle fina e móvel. Medialmente nota-se a saliência formada pelo músculo bucinador que torna a região convexa. A parte posterior, correspondente ao chato da bochecha é completamente plana, e tem por base, em toda a extensão, como dissemos, o $M$. masseter.

Narina: - Região par, representada pelos orifícios exteriores das cavidades nasais (Est. 1 e 2 I). As narinas são duas aberturas colocadas de cada lado da região da extremidade do nariz, convergindo inferiormente em fórma de elipse ou, como mais comumente se compara, idênticas a duas vírgulas com seus bórdos convexos voltados lateralmente.

Limites: - Superiormente cada narina ou venta é limitada pela região do chanfro; lateral e anteriormente, pelo lábio superior e medialmente, pela extremidade do nariz.

Linhas de demarcação: - A demarcação de seu contôrno é dada pela linha que acompanha, cerca de um centímetro, suas asas: interna e externa e comissuras: superior e inferior.

Há certa discordância entre os AA. em estabelecer diferenciação entre - narinas, divertículo do nariz e vestíbulo do nariz - elementos que constitúem a extremidade oral das cavidades nasais.

BRUNI, nas suas pesquisas morfológicas sôbre o divertículo nasal dos Equinos domésticos, diz que para os antigos anatomistas, narina significava toda a cavidade nasal. A denominação de falsa narina, pelo mesmo motivo, significaria, então, falsa cavidade nasal.

Outros AA. usam a denominação narina para o vestíbulo do nariz, porém, para B. N. A. o termo nares, ou naris (I. N. A. - 1935) significa abertura externa da cavidade nasal - apertura nasi externa -, denominação esta que julgamos mais exata e que deve ser adotada.

A préga cutânea, representada por um fundo cégo, colocado no angulo formado pela incisura inter-maxilo-nasal, errôneamente denominada falsa narina, será chamada divertículo do nariz ou como ainda prefére BRUNI divertículo cutâneo do nariz ou divertículo do vestíbulo do nariz. Acha, êste A., as últimas denominações mais exatas, porquanto, divertículo do nariz são todas as cavidades acessorias das fóssas nasais.

Falsa narina não seria, então, sinônimo de divertículo cutâneo do nariz, mas compreenderia a parte dorsal da narina (apertura nasi externa), pela qual se tem acésso à cavidade do divertículo cutâneo, sem penetrar nas fóssas nasais.

Tôda a porção da cavidade nasal que possúe revestimento cutâneo seria denominada de vestíbulo do nariz, Bruni. Kormann que es- 
tudou muito bem, por pesquisas histológicas, os limites entre vestíbulo e cavidade nasal pròpriamente dita considerou-os muito nítidos em animais pigmentados, onde se nota a passagem brusca da péle para a mucósa. O mesmo não acontece com a delimitação entre vestíbulo e divertículo cutâneo do nariz, pois que, nêste ponto, os limites não estão bem estabelecidos pelos AA..

Para Ellenberger e Baum, o vestíbulo e divertículo cutâneo do nariz são compreendidos sob o nome de nariz cutâneo (nasus cutanius).

Embóra esta região receba a denominação que anatômicamente compreende exclusivamente a abertura externa das fóssas nasais, em Exterior, além desta abertura, estudam-se tambem o vestíbulo do nariz e seu divertículo cutâneo, estendendo-se ainda mais internamente para as fóssas nasais, porquanto, a pituitária é, igualmente levada em consideração, quando são estudadas as belezas e defeituosidades da região.

A narina, na respiração socegada, tem a fórma de um crescente ou de uma vírgula invertida, com a convexidade voltada ventrolateralmente; na respiração profunda, apressada, intensa, toma mais a fórma ovalar, com a grande curvatura voltada ventralmente.

Os limites da narina são dados pelas asas do nariz, das quais, a medial tem como arcabouço a cartilagem alar, enquanto que a lateral, sòmente na porção ventral alberga, em seu interior, o corno da cartilagem alar, no restante é móve: e flexivel, entrando em sua constituição músculos e tecido conjuntivo. Na porção ventral, as asas do nariz continuam-se uma na outra formando uma dôce curva, ao passo que a comissura dorsal se faz em angulo agúdo.

Do acima exposto, fica bem claro que pela porção dorsal da narina (comissura dorsal) - falsa narina BRUNI; penetra-se no divertículo cutâneo do vestíbulo do nariz e, pela porção ventral (comissura ventral), penetra-se pelo vestíbulo do nariz, nas cavidades nasais pròpriamente ditas.

Achamos oportuno lembrar que BRUNI, no estudo já mencionado, considera o orifício da narina como uma formação secundária e, segundo êste critério, o orifício externo vestibular seria limitado lateralmente, como nos outros animais, pela as que tem como arcabouço a cartilagem alar. Dêste módo, para êste A., é improprio empregar o termo de asa lateral para a dóbra cutânea, de crescimento secundário, que aparece limitando lateralmente o contôrno da narina. BRUNI de preferencia usa a denominação parede lateral do nariz cutâneo em substituição a de asa lateral. 


$$
\text { C - FACE POSTERIOR }
$$

A face posterior da cabeça compreende tôda a região que se estende da garganta à protuberância do mento, apresentando ao estudo ezoognosico três regiões: - fauce, ganachas e barba.

Fauce: - E' uma região ímpar, situada entre os dois ramos da mandíbula (Est. $3 \mathrm{~J}$ ).

Limites: - Tem como limite aboral a garganta. Oralmente continúa-se com a barba e lateralmente com as ganachas.

Linhas de demarcação: - Lateralmente a fauce é demarcada pela saliência nítida formada pelos bórdos inferiores da mandíbula, que a separam da ganacha. Estes bórdos, reunindo-se na sínfise mandibular, constitúem a demarcação oral separando a fauce da barba. Seu limite aboral é dado por uma transversal que une os dois angulos da mandíbula, limitando esta região com a da garganta.

Descrição: - Preenchendo todo o espaço inter-mandibular, a fauce apresenta-se com fórma de um $\mathrm{V}$, com vértice oral, deprimido em relação aos bórdos inferiores da mandíbula, que constitúem, mesmo, seus limites.

A péle desta região é fina, entremeada de pêlos longos, principalmente nos animais linfáticos.

A abundância do tecido celular subcutâneo em sua porção aboral, permite o maior deslocamento da péle, necessário à bôa movimentação da cabeça.

Ganacha: - Região par, situada de cada lado da fauce, estendendo-se pelo ramo horizontal, angulo e ramo ascendente da mandíbula (Est. $3 \mathrm{~K}$ ). Na porção correspondente ao ramo horizontal da mesma, só entra na constituição desta região, o bórdo ventral do osso. Atingindo o angulo e o ramo ascendente, estende-se sôbre a face medial dessas porções ósseas, onde se continúa com a região da garganta.

Limites: - Aboralmente limita-se com a garganta e parótida, oralmente continúa-se com a barba e medialmente, com a fauce.

Linhas de demarcação: - As linhas de demarcação desta região podem ser dadas por tôda a extensão dos bórdos ventrais da mandíbula, dêsde o angulo, aboralmente, até o corpo, oralmente. Na porção correspondente ao angulo e ramo ascendente, esta região, como vimos, ultrapassa o bórdo, para se estender em parte sôbre a face medial do osso, servindo como ponto de reparo para sua delimitação medial, a reflexão da péle sôbre a garganta. 
Descrição: - A ganacha pode ser dividida em duas partes, por uma saliência situada na altura do limite entre a porção massetérica da bochecha e a bolsa da mesma, saliência esta formada pela artéria e veia faciais e canal de Stenon. A parte anterior é fàcilmente explorada pela palpação, o que não se dá com a posterior, devido à sua quasi confusão com as regiões vizinhas. E' na face interna da porção aboral que tomamos os batimentos arteriais no cavalo, comprimindo a artéria maxilar externa contra a face interna da mandíbula.

A péle desta região é delgada e móvel sôbre o plano ósseo.

Barba: - E' a região ímpar situada imediatamente atrás da protuberância do mento, onde repousa a barbéla do freio. (Est. $3 \mathrm{~L}$ ).

Limites: - Oral e lateralmente limita-se com o lábio inferior, aboral e lateralmente continua-se, de cada lado, com as ganachas e posteriormente, com o vértice da fauce.

Linhas de demarcação: - Oralmente é separada do lábio por uma linha que margeia o bórdo aboral da protuberância do mento. Seu limite aboral, corresponde ao bórdo posterior do corpo da mandíbula, limite que a separa da fauce. As linhas de demarcação laterais são traçadas pela reunião dos limites oral e aboral e correspondem, profundamente, às margens laterais do corpo da mandíbula.

Descrição: - A barba é uma região de pequena extensão, que não apresenta interesse importante para uma descrição mais ou menos detalhada. Certos AA. querem vêr, na conformação da mesma, caracteres etológicos secundários (MARCHI), descrevendo-a mais arredondada nos animais novos e cortante nos de idade avançada. Não há, entretanto, observações precisas à respeito.

\section{D - EXTREMIDADE INFERIOR OU ÁPICE}

A extremidade inferior da cabeça apresenta como única região a estudar - a bôca, parte de grande importancia em Ezoognosia, onde, além de se estudar sua abertura, faz-se descrição detalhada dos dentes, gengivas, barras, língua, palato e canal lingual.

Bôca: - Sendo o fim dêste trabalho, como tivemos ocasião de dizer, delimitar as regiões externamente, dar-se-à apenas a demarcação e descrição de seu contôrno oral formado pelos lábios superior e inferior (Est. 1,2 e $3 \mathrm{M}$ ).

Limites: - Superiormente limita-se com a extremidade do nariz; lateral e dorsalmente com as narinas, lateralmente com as bochechas e inferiormente com a barba. 
Linhas de demarcação: - A linha de demarcação superior corresponde, internamente, ao sulco gengivo-labial, limite oral da extremidade do nariz. Dorso-lateralmente segue, a cerca de 1 centímetro o contôrno da narina, limitando-se com esta região, até a parte média da asa lateral, ponto de terminação das linhas divisórias do chanfro e bochecha. Margeia a saliência do músculo orbicular, acompanha lateralmente a comissura dos lábios, até atingir a porção mais lateral e posterior da protuberância do mento, limite oral da bochecha. Ventralmente, a bôca separa-se da barba por um sulco bem nítido, que passa pelo limite posterior da protuberância do mento.

Descrição: - A bôca é fechada anteriormente por duas prégas músculo-membranosas - os lábios - uma superior e outra inferior e que, nos equinos, são utilizadas como órgão de preensão dos alimentos, sendo ainda, sob o ponto de vista do Exterior, órgãos de expressão.

O lábio superior, mais móvel, toma parte mais saliênte na preensão dos alimentos. A péle, tanto do lábio superior, como do inferior, pode apresentar-se branca, nos animais de pelagem escura, que são denominados: Bébe no branco do lábio superior, inferior ou de ambos.

Os lábios oferecem ao estudo duas faces, externa e interna; dois bórdos, livre e aderente e duas comissuras.

A face externa, anterior ou cutânea do lábio superior é convexa, apresentando um sulco mediano denominado sub-nasal, que a divide em duas saliências pouco nítidas. A face cutânea do lábio inferior não apresenta êste sulco, mas sim, prégas semi-circulares, que a separam da protuberância do mento. Esta face é revestida de pêlos comúns e tacteis, sendo que na do lábio superior, de cada lado do sulco sub-nasal, pode notar-se uma grande quantidade de pêlos longos, agrupados em feixes, formando verdadeiros bigódes.

A face interna, posterior ou mucósa, é côncava e se colóca sôbre a face anterior das gengivas e arcadas dentárias, sendo revestida pela mucósa lábial que se continúa pela mucósa gengival. Esta face é lisa, de côr rósea pálida, apresentando algumas vezes manchas pigmentadas.

O bórdo livre, arredondado, marca a transição entre a péle e a mucósa. E' regular nos primeiros anos de vida, tornando-se rugoso com o avançar da idade.

O bórdo aderente é nivelado pela reflexão da mucósa labial sôbre a gengiva, que constitúe os sulcos gengivo-labiais superior e inferior.

As comissuras são arredondadas e se colocam lateralmente, proximo à metade das barras. 


\section{E - EXTREMIDAdE SUPERIOR OU BASE}

A extremidade superior da cabeça é representada por duas regiões ímpares - nuca e garganta - e uma par - parótidas.

Alguns AA. como Goubaux e Barrier, Le Hello, Bourdelle e Bressou, Marce e Lahaye, Duerst e outros, inclúem tais regiões na parte posterior da cabeça, estudando-as, como faremos, na extremidade superior.

Outros como: Faelli, Marchi, Gmelin, Rubay, consideram-nas como regiões intermediárias entre a cabeça e o pescoço, estudando-as à parte.

Nuca: - A nuca que no homem se estende da protuberância occipital externa e linhas curvas occipitais superiores, pela face posterior do pescoço até a 7.a vértebra cervical, nos animais, está colocada entre as orelhas, correspondendo à regiăo mais alta da cabeça e anteriormente ao bórdo superior do pescoço (Est. $2 \mathrm{e} 4 \mathrm{~N}$ ).

Limites: - Oralmente a nuca está limitada pela fronte; lateralmente com as orelhas e parótidas e posteriormente, com a parte mais anterior do bórdo superior do pescoço.

Linhas de demarcação: - Oralmente esta região é demarcada pela linha transversal que acompanha a porção mais alta da cabeça, representada pela protuberância occipital externa e linha superior da nuca. O limite aboral é representado pela linha transversal que acompanha o bórdo ou margem anterior do atlas, que tem sua porção mais evidente nas saliências da porção cranial das asas do mesmo osso, separando a nuca, da região cervical superior. Lateralmente, tomando como ponto de partida a porção extrema da linha superior da nuca, a demarcação da região se faz acompanhando a base da concha, no ponto de reflexão da péle. Segue, depois, a córda muscular formada pelo músculo pequeno obliquo da cabeça, que passa acima da região da parótida, até atingir a parte anterior da asa do atlas.

Descrição: - Nuca, região de extensão mínima, é representada por uma faixa transversal, onde se reconhece uma porção mediana e duas laterais. A primeira é recoberta por uma péle grossa e aderente, na qual se implanta um tufo de pêlos denominado topéte. As regiões laterais apresentam a péle mais fina, menos aderente, e são recobertas por pêlos comúns.

Garganta - E' a região que compreende tôda a porção representada pela préga do pescoço sobre a cabeça e reúne as duas parótidas inferiormente (Est. 2 e 3O). 
Limites: - Anteriormente limita-se com as fauces; superolateralmente com as ganachas e parótidas; posteriormente se continúa com o limite anterior do bórdo inferior do pescoço.

Linhas de demarcação: - A linha de demarcação oral é dada por uma transversal, que une os dois angulos da mandíbula. A aboral, posterior à saliência muito perceptivel do bórdo postero-ventral da cartilagem cricóide, corresponde internamente aos primeiros anéis da traquéa e separa a garganta da região do pescoço. Lateralmente sua demarcação é dada pela linha que, partindo do ponto de reflexão da péle lógo acima do angulo da mandíbula sôbre a face medial do ramo montante, se dirige para trás até cruzar a linha imaginária que prolonga o relêvo anterior da asa do atlas até atingir o bórdo ventral do pescoço. Esta linha separa a garganta da ganacha e parótida.

Descrição: - A péle desta região é delgada e muito móvel, apresentando prégas transversais, que desaparecem quando a cabeça se estende.

Parótida: - E' uma região par, situada lateralmente à cabeça, constituindo para alguns autores a região intermediária entre esta e as paredes laterais ou táboas do pescoço (Est. 2e $4 \mathrm{P}$ ).

Limites: - Superiormente, limita-se com a orelha; inferiormente, com a garganta; anteriormente, com a bochecha e a têmpora e posteriormente, com a táboa do pescoço.

Linhas de demarcação: - Superiormente a parótida separa-se da orelha por uma linha de concavidade dorsal, que contórna lateralmente a base da concha, no ponto de reflexão da péle, abraçando-a aboral e oralmente. Separa-se da nuca pela córda saliênte formada pelo músculo pequeno obliquo. A linha de demarcação inferior é traçada do angulo da mandíbula para trás, até atingir a linha imaginária que prolonga para baixo o relêvo anterior da asa do atlas. Oralmente, a linha de demarcação parte da porção mais aboral da arcada zigomática, contórna posteriormente a articulação têmporo-mandibular, segue pelo ramo ascendente da mandíbula, até seu angulo, onde se une com o limite inferior. Aboralmente demarca-se a região da parótida pelo relêvo anterior da asa do atlas prolongado inferiormente por uma linha imaginária, até ao ponto de cruzamento com a da demarcação inferior.

Descrição: - A região da parótida é recoberta por uma péle bastante móvel que se prega transversalmente quando a cabeça entra em flexão. A glandula parótida ocupa tôda a extensão da região, feita exceção de uma pequena parte situada no angulo antero-inferior, 
que é cruzada pelo músculo digástrico e pelo tendão do músculo esterno-maxilar.

Esta contribuição para o estudo da demarcação das regiões da cabeça no cavalo, é a primeira de uma série de trabalhos que pretendemos encetar, nos quais abordaremos sucessivamente as demais regiões do corpo dêsse animal. Do mesmo modo, é nosso intuito estender identico estudo às demais especies domesticas. 


\section{BIBLIOGRAFIA}

Arroyo, V. M. - 1934 - Manual de Anatomia Descritiva del caballo y atlas. Buenos Aires. Rodolfo Isely.

Bourdelle, E. \& Bressou, C. - 1937 - Anatomie regionale des animaux domestiques. T. I. fasc. II, 2e. ed. Paris. Baillière et Fils.

Bruni, A. C. - 1918 - Sul «Diverticulum nasi» degli Equini domestici. Estratto dell' Archivio per le Scienze Mediche, 41, (8).

Chaves de Lemos, A. A. - 1903 - O cavalo. Porto. De Lello \& Irmãos.

Duerst, J. U. - 1922 - Die Beurteilung des Pferdes. Stuttgart. Ferdinand Enke.

Ellenberger, W. \& Baum, H. - 1932 - Handbuch der vergleichenden Anatomie der Haustiere. 17 Aufl. Berlin. Julius Springer.

Ellenberger, W. \& Baum, H. - 1914 - Lehrbuch der Topographischen Anatomie des Pferdes. Berlin. Paul Parey.

FAVILLI, N. - 1931 - Nozioni comparate di Anatomia e Fisiologia degli animali rurale, Torino. Un. Tip. Ed. Torinese.

Gmelin, W. - 1925 - Das Aüssere des Pferdes. Stuttgart. Schickhardt \& Ebner.

Goubaux, A. \& Barrier, A. - 1890 - L'Exterieur du cheval. Paris. Asselin \& Cie,

Kormann, Bodo - 1905 - Über den Bau des integuments der Regio narium und der Wand des Nasenvorhofes der Haussäugetiere. Inaugural-Dissertation - Giessen.

Lesbre, F. X. - 1922 - Anatomie Comparée des animaux domestiques. - T. I. Paris. Baillière et Fils.

Lesbre, F. X. - 1930 - Précis d'Exterieur du cheval et des principaux mammifères domestiques, 3e. ed. Paris. Vigot Frères.

Magliano, A. - 1930 - Ezoognosia generale. Torino. Un. Tip. Ed. Torinese.

Marchi, E. - s. d. - Ezoognosia. Vol. I. Milano. Francesco Vallardi.

Marce, J. \& Lahaye, J. - 1934 - Exterieur du cheval. Gembloux. Jules Duculot.

Mongiardino, T. - 1903 - Trattato di Anatomia topografica dei mammiferi domestici. Torino. Luigi Delgrosso.

Noguerra, O. R. - 1920 - Exterior dos grandes animais domésticos. São Paulo. Soc. Ed. Olegario Ribeiro.

Rubay, P. - 1932 - Tratado de Anatomia topografica del caballo, 2a ed. Madrid. Agencia Española de Libreria.

Schmaltz, R. - 1928 - Anatomie des Pferdes. 2 Aufl. Berlin.

Sisson, S. - 1933 - Anatomia de los animales domesticos. Barcelona. Salvat Editores S. A.

Zanollı, C. -1910 - Manual de Anatomia veterinária. T. I. La Plata. Felix S. Santi.

ZimmerL, U. - 1929 - Trattato di Anatomia veterinaria. Vol. I. Milano. Francesco Vallardi. 


\section{EXPLICAÇÃO DAS ESTAMPAS}

Estampa 1 - Face anterior da cabeça.

Estampa 2 - Face lateral da cabeça.

Estampa 3 - Face posterior da cabeça.

Estampa 4 - Extremidade superior da cabeça.

Indicações comuns das estampas

A - Fronte

B - Chanfro

C - Extremidade do nariz

D - Orelhas

E - Têmporas

F - Olhais

G - Regiôes orbitárias

$\mathrm{H}$ - Bochechas

1 - Narinas

J - Fauce

K - Ganachas

L - Barba

M-Boca

$\mathrm{N}$ - Nuca

O - Oarganta

P - Parótida. 


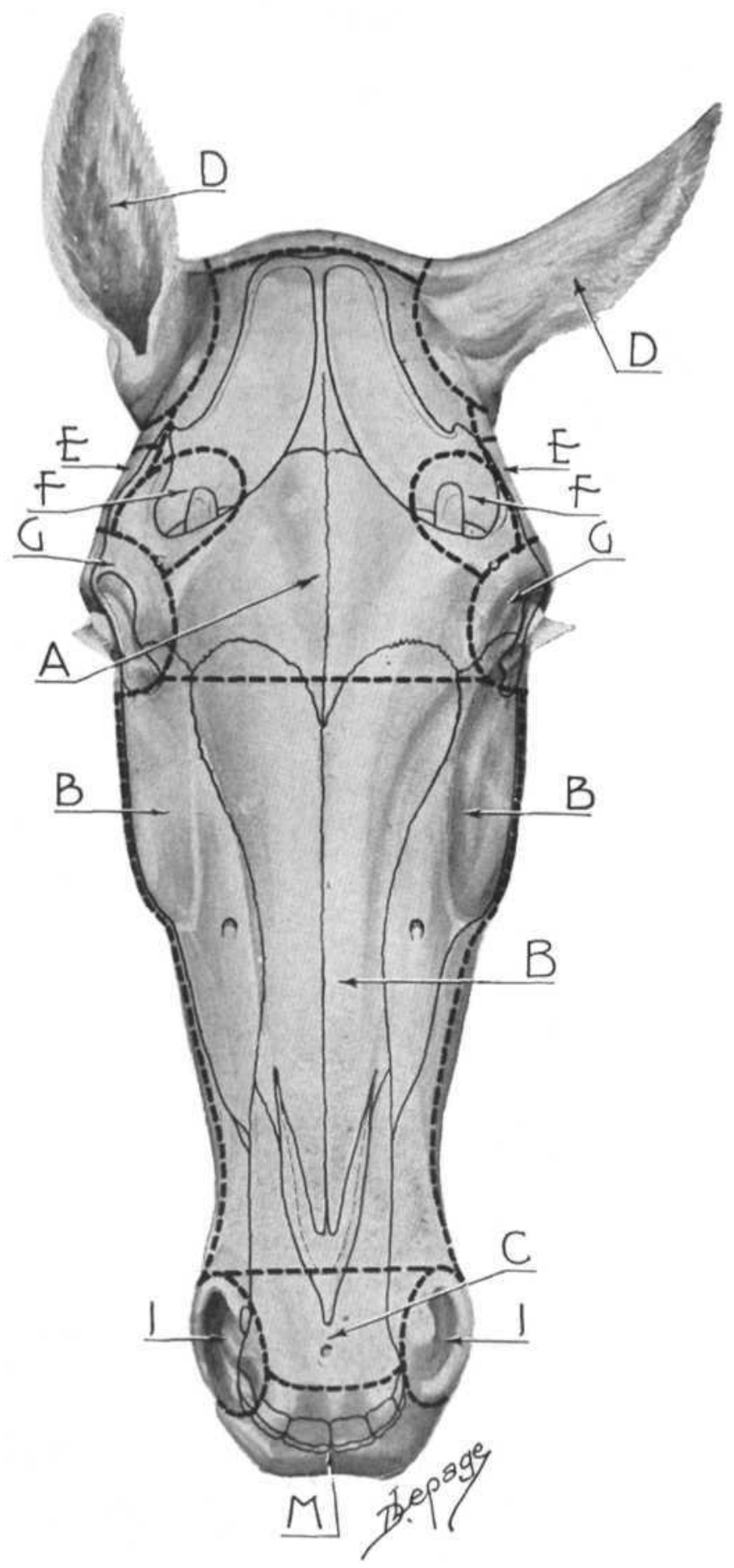




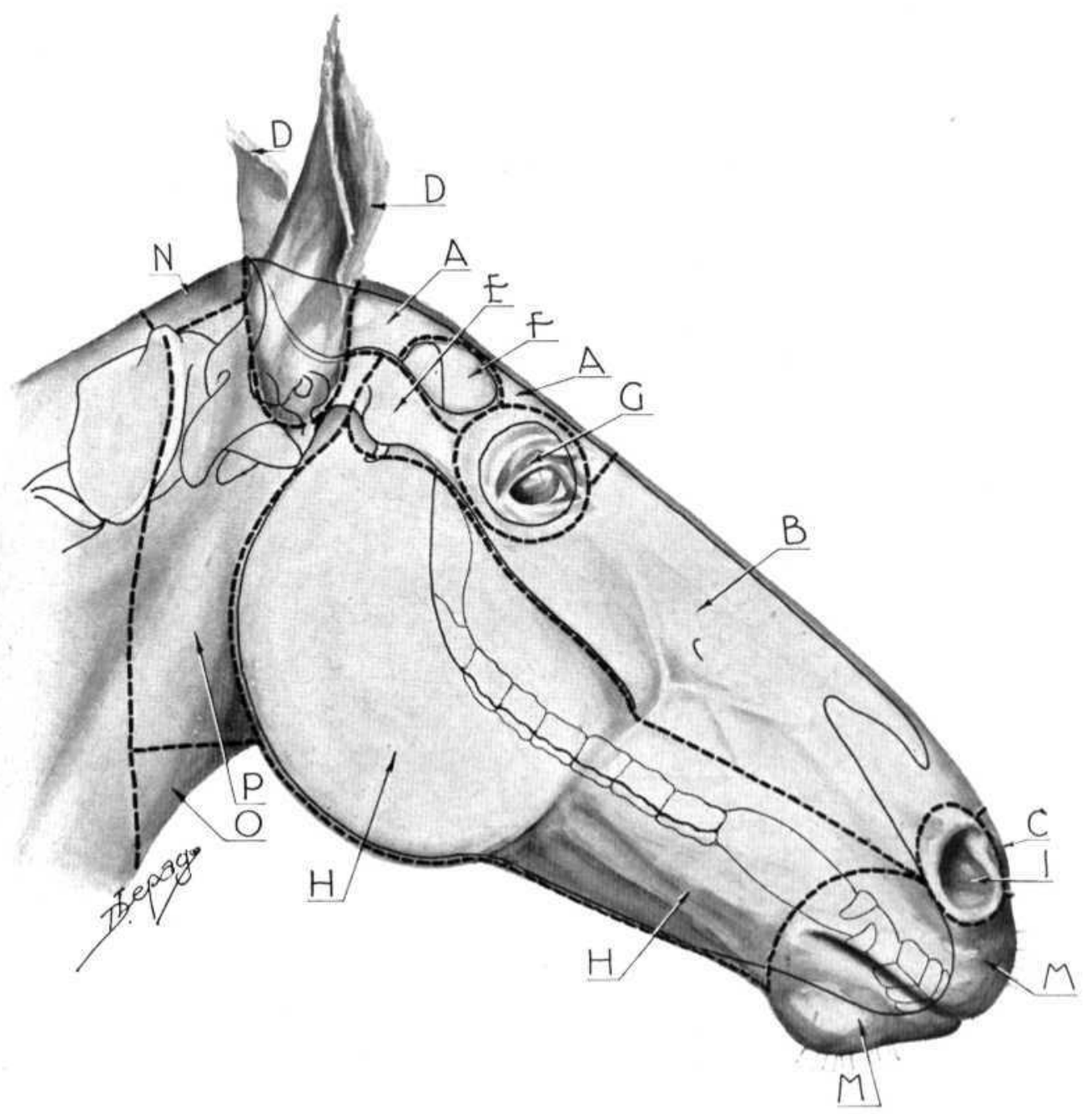




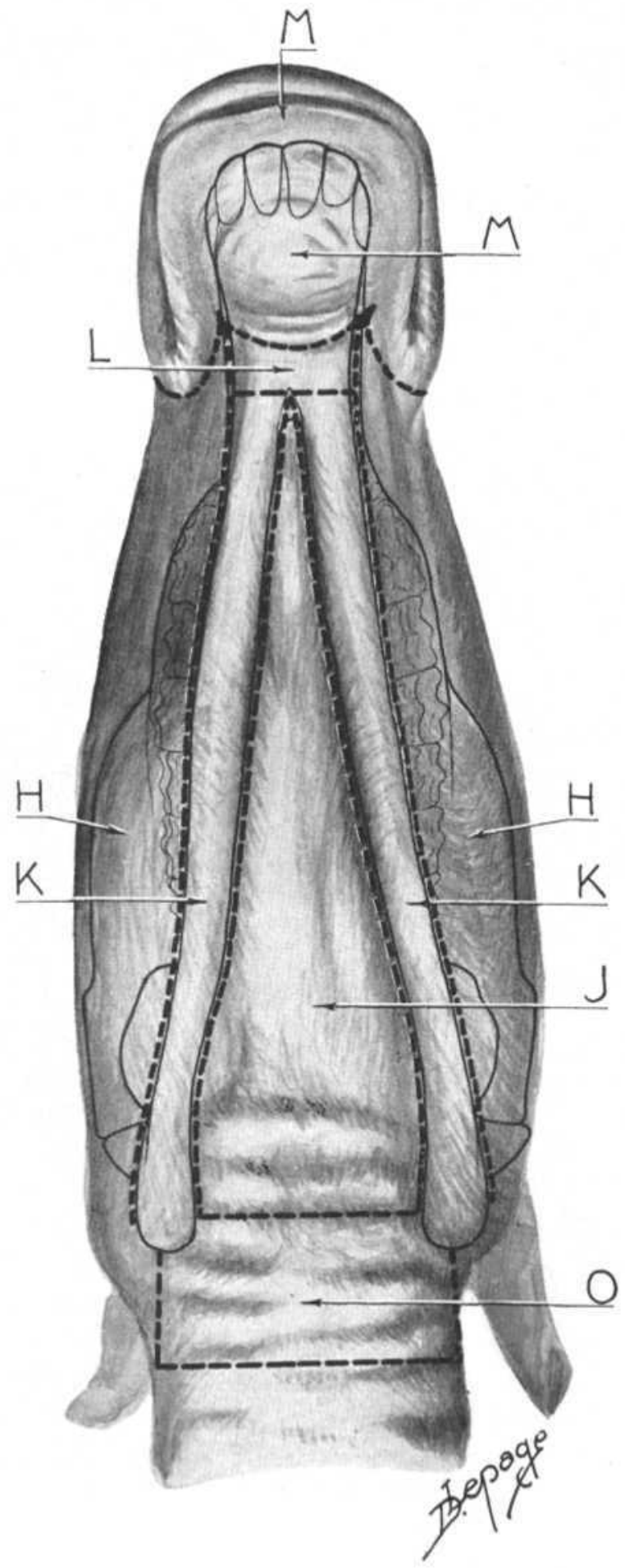




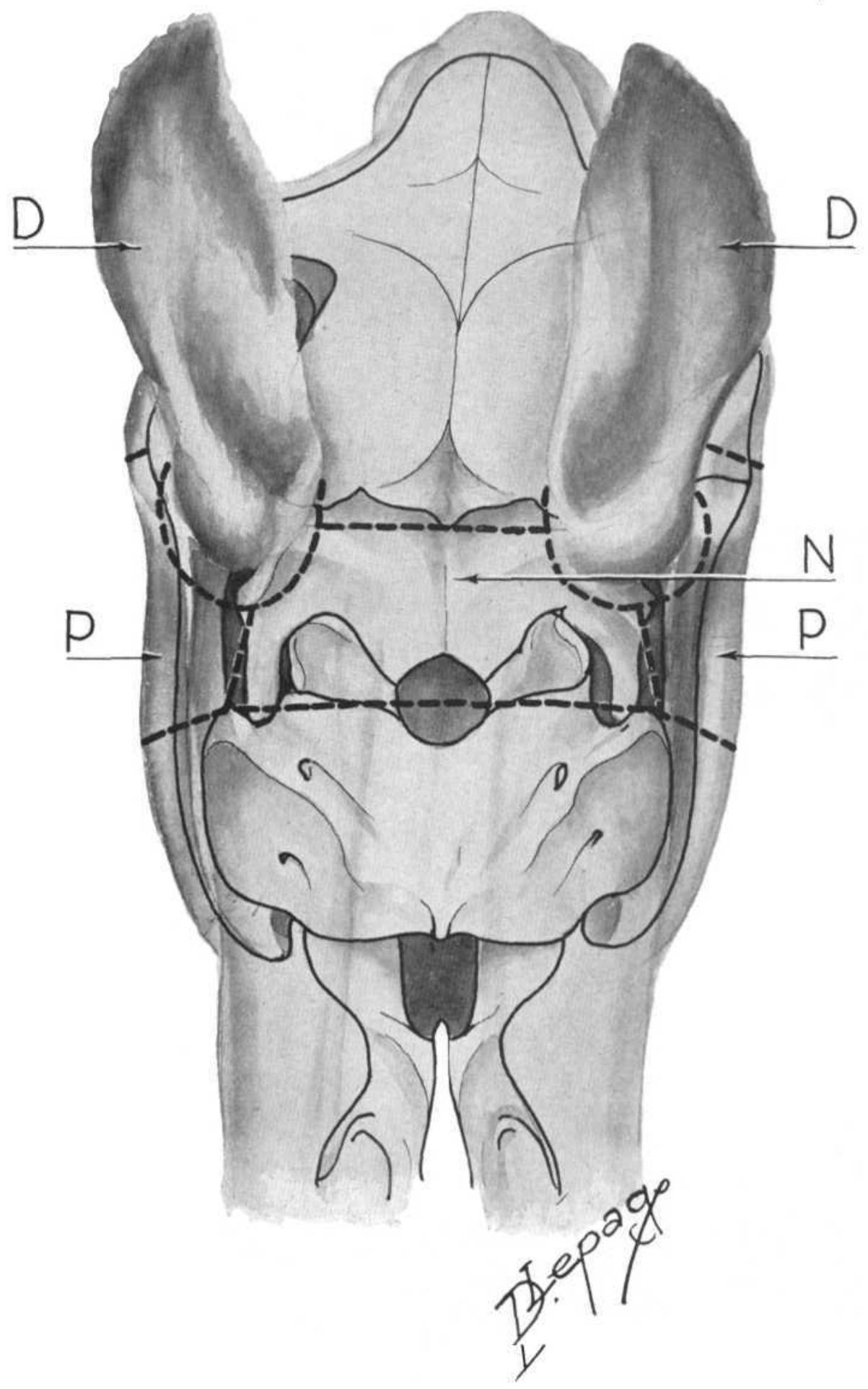

